\title{
CHARACTERIZATION OF BULK SOIL HUMIN AND ITS ALKALINE-SOLUBLE AND ALKALINE-INSOLUBLE FRACTIONS
}

\author{
Cuilan Li(1), Shuqing Gao(1), Qiang Gao(1), Lichun Wang(2) and Jinjing Zhang(1)*
}

\author{
(1) Jilin Agricultural University, College of Resource and Environmental Science, Changchun, China. \\ (2) Institute of Agricultural Resources and Environments, Jilin Academy of Agricultural Sciences, Changchun, China. \\ * Corresponding author. \\ E-mail: zhangjinjing@126.com
}

\begin{abstract}
Humic substances are the major components of soil organic matter. Among the three humic substance components (humic acid, fulvic acid, and humin), humin is the most insoluble in aqueous solution at any $\mathrm{pH}$ value and, in turn, the least understood. Humin has poor solubility mainly because it is tightly bonded to inorganic soil colloids. By breaking the linkage between humin and inorganic soil colloids using inorganic or organic solvents, bulk humin can be partially soluble in alkali, enabling a better understanding of the structure and properties of humin. However, the structural relationship between bulk humin and its alkaline-soluble (AS) and alkaline-insoluble (AIS) fractions is still unknown. In this study, we isolated bulk humin from two soils of Northeast China by exhaustive extraction (25 to 28 times) with $0.1 \mathrm{~mol} \mathrm{~L}-1 \mathrm{NaOH}+0.1 \mathrm{~mol} \mathrm{~L}-1 \mathrm{Na}_{4} \mathrm{P}_{2} \mathrm{O}_{7}$, followed by the traditional treatment with $10 \% \mathrm{HF}-\mathrm{HCl}$. The isolated bulk humin was then fractionated into AS-humin and AIS-humin by exhaustive extraction (12 to 15 times) with 0.1 mol L-1 $\mathrm{NaOH}^{- \text {Elemental }}$ analysis and solid-state ${ }^{13} \mathrm{C}$ cross-polarization magic angle spinning nuclear magnetic resonance (13C CPMAS NMR) spectroscopy were used to characterize and compare the chemical structures of bulk humin and its corresponding fractions. The results showed that, regardless of soil types, bulk humin was the most aliphatic and most hydrophobic, AS-humin was the least aliphatic, and AIS-humin was the least alkylated among the three humic components. The results showed that bulk humin and its corresponding AS-humin and AIS-humin fractions are structurally differed from one another, implying that the functions of these humic components in the soil environment differed.
\end{abstract}

Keywords: soil humic substances, humin fractionation, elemental composition, $13 \mathrm{C}$ NMR. 


\title{
RESUMO: CARACTERIZAÇÃO DA DENSIDADE DE HUMINA E SUAS FRAÇÕES ALCALINAS SOLÚVEIS E ALCALINAS INSOLÚVEIS
}

\begin{abstract}
Em razão da sua insolubilidade, a humina é o componente menos compreendido das substâncias húmicas do solo. Essa insolubilidade deve-se principalmente à forte ligação desse componente aos coloides inorgânicos do solo. Ao quebrar a ligação entre humina e coloides do solo, utilizando alguns solventes orgânicos ou inorgânicos, a humina total pode ser parcialmente solúvel em álcali, permitindo uma compreensão mais profunda da estrutura e das propriedades da humina. No entanto, a relação entre humina e as frações de humina solúvel (AS), e insolúvel (AIS) em meio alcalino, ainda são desconhecidas. Neste estudo, foi isolada a humina de dois solos do nordeste da China, municipio de Changchun, usando exaustiva extração com $\mathrm{NaOH} 0,1 \mathrm{~mol} \mathrm{~L}-1+\mathrm{Na}_{4} \mathrm{P}_{2} \mathrm{O}_{7}$ 0,1 mol L-1 (25 a 28 vezes), seguido por tratamento tradicional $\mathrm{HF}$ - $\mathrm{HCl}$ a $10 \%$. A humina isolada foi então fracionada nas frações AS-humina e AIS-humina por extração exaustiva com $\mathrm{NaOH} \mathrm{0,1} \mathrm{mol} \mathrm{L-1} \mathrm{(12} \mathrm{a} 15$ vezes). A análise de Ressonância Magnética Nuclear do ${ }^{13} \mathrm{C}$ em estado sólido, usando a técnica de polarização cruzada e o ângulo mágico (13C CPMAS RMN), foi utilizada para caracterizar e comparar as estruturas químicas de humina e suas frações correspondentes. Os resultados evidenciaram que, independentemente do tipo de solo, a humina total era a mais alifática e mais hidrófobica, AS-humina foi a menos alifática e AIS-humina foi a menos alquilada entre as três componentes húmicas. Os resultados demonstraram que a humina total e suas correspondentes frações AS-humina e AIS-humina são estruturalmente diferentes uma da outra, o que implica que há diferença entre as funções desses componentes húmicos no ambiente.
\end{abstract}

Palavras-chave: substâncias húmicas do solo, fração húmica, composição elementar, ${ }^{13}$ C NMR.

\section{INTRODUCTION}

Humic substances are the most ubiquitous and widespread natural nonliving organic compounds in the environment (Senesi, 2010). They account for approximately 60 to $75 \%$ of the total organic matter in soil (Grinhut et al., 2011). Soil humic substances have an important function in many environmental processes such as $\mathrm{C}$ sequestration, nutrient cycling, and pollutant retention (Rice, 2001; Zhang et al., 2013). The beneficial effects of soil humic substances are mainly ascribed to their complex chemical structure and properties. Thus, understanding the structural characteristics of soil humic substances is important for clarifying their mechanisms of action in environmental processes.

Humic substances are generally divided into three main components based on their solubility in aqueous solutions at different $\mathrm{pH}$ values, namely, humic acid, fulvic acid, and humin (Stevenson, 1994). Among the three humic substance components, humin is the most insoluble and, in turn, the least understood component. The poor solubility of humin is mainly due to its close association with the inorganic soil colloids, especially swelling clays and iron compounds (Cloos et al., 1981; Rice, 2001). By breaking the linkage between humin and inorganic soil colloids using inorganic (e.g., $\mathrm{HF}, \mathrm{H}_{2} \mathrm{SO}_{4}$, and $\mathrm{Na}_{2} \mathrm{~S}_{2} \mathrm{O}_{3}$ ) and organic (e.g., MIBK, urea, and DMSO) solvents, it is possible to recover and separate bulk humin into soluble and insoluble fractions (Pallo, 1993; Stevenson, 1994; Rice, 2001; Song et al., 2005; Spaccini et al., 2006; Song et al., 2011). The fractionation of humin can reduce its insolubility as well as heterogeneity. Thus, the structure and properties of humin can be further understood. Traditionally, the HF or HF-HCl treatment has most commonly been used to recover bulk humin from inorganic soil colloids (Stevenson, 1994; Rice, 2001; Calace et al., 2007). The soluble fraction can subsequently be isolated from the insoluble fraction of bulk humin by alkaline extraction (Song et al., 2005; Spaccini et al., 2006). However, to the best of our knowledge, the structural relationship between bulk humin and its alkaline-soluble and alkaline-insoluble fractions is still unknown.

The purpose of the present study is to compare the structural characteristics among bulk humin and its alkaline-soluble and alkaline-insoluble fractions from two soils of Northeast China using the elemental analysis and solid-state ${ }^{13} \mathrm{C}$ CPMAS NMR techniques to provide new information and improve our understanding of the chemical structure of humin in the soil environment.

\section{MATERIAL AND METHODS}

The soils used in the study were developed from Quaternary Loess Deposit and classified as Luvic Phaeozem and Haplic Chernozem (FAO/ISRIC/ISSS, 1998). The Luvic Phaeozem were collected from a maize (Zea mays L.) field located in Changchun city $\left(43^{\circ} 57^{\prime} 10.7^{\prime \prime} \mathrm{N}, 125^{\circ} 24^{\prime} 45.0^{\prime \prime} \mathrm{E}\right)$, Northeast China, with mean annual pluvial precipitation of $565.0 \mathrm{~mm}$ and mean annual temperature of $4.8^{\circ} \mathrm{C}$. 
The Haplic Chernozem were from uncultivated land located in Nong'an County $\left(44^{\circ} 11^{\prime} 39.7^{\prime \prime} \mathrm{N}\right.$, $\left.125^{\circ} 07^{\prime} 58.5^{\prime \prime} \mathrm{E}\right)$, Northeast China, with mean annual pluvial precipitation of $507.7 \mathrm{~mm}$ and a mean annual temperature of $4.7^{\circ} \mathrm{C}$. Soil samples were taken from the top $0-20 \mathrm{~cm}$ depth, air-dried, and ground to pass through a $2 \mathrm{~mm}$ sieve. The soil characteristics were analyzed using the recommended procedure (Lao, 1988), and the results are shown in the table 1.

Humin and its fractions were extracted and purified at room temperature as previously described (Song et al., 2005; Spaccini et al., 2006; Zhang et al., 2009, 2013) with some modifications. In brief, the soil sample (100 g) was shaken in centrifuge tubes with distilled water and $0.1 \mathrm{~mol} \mathrm{~L}^{-1}$ $\mathrm{HCl}$ solution at a soil/solution ratio of 1:10 to remove poorly decomposed light fractions and carbonates, respectively. The sample was then extracted with $0.1 \mathrm{~mol} \mathrm{~L}^{-1} \mathrm{NaOH}+0.1 \mathrm{~mol} \mathrm{~L}^{-1} \mathrm{Na}_{4} \mathrm{P}_{2} \mathrm{O}_{7}$ at a soil/extractant ratio of $1: 10$ for $24 \mathrm{~h}$ to remove alkaline-soluble humic and fulvic acids. The extraction was repeated 25 to 28 times until the supernatant was almost colorless. The alkaline-insoluble solid residue (designated as crude humin), which accounted for $97-98 \%$ of the initial mass of the soil sample, was successively treated 30 times with $10 \% \mathrm{HF}-\mathrm{HCl}$ solution at a 1:10 soil/liquid ratio. Our previous study has shown that the exhaustive acid pre-treatment was applicable to characterize the chemical structures of soil humin (Zhang et al., 2009). The HF-HCl treatment can effectively remove the mineral matrix, concentrate organic matter, and enhance the signal-to-noise ratio of solid-state ${ }^{13}$ C NMR spectra (Kögel-Knabner, 1997; Schmidt et al., 1997). After the HF-HCl treatment, the residue was rinsed with $10 \% \mathrm{HCI}$ to eliminate secondary minerals such as the fluorite formed during demineralization. The resulting humin (designated as bulk humin) was washed with distilled water until the supernatant was $\mathrm{Cl}^{-}$-free, oven-dried at $50^{\circ} \mathrm{C}$, and ground to $<0.1 \mathrm{~mm}$.

The bulk humin sample was further extracted with $0.1 \mathrm{~mol} \mathrm{~L}^{-1} \mathrm{NaOH}$ solution using a 1:100 sample/extractant ratio. The alkaline treatment was repeated 12 to 15 times until the supernatant was almost colorless. The combined dark-colored supernatants, which were designated as alkaline-soluble humin (AS-humin), were acidified with $6 \mathrm{~mol} \mathrm{~L}^{-1} \mathrm{HCl}$ to $\mathrm{pH}$ 1. The acid-soluble fraction was colorless and hence discarded. The acid-insoluble fraction, which was used to represent AS-humin, was dialyzed in cellophane bags against distilled water until $\mathrm{Cl}^{-}$-free. After the extraction, the final solid residue, which was designated as alkaline-insoluble humin (AIS-humin), was washed to neutrality with distilled water. Both AS- and AIS-humin were freeze-dried and then ground to $<0.1 \mathrm{~mm}$.

The $\mathrm{C}, \mathrm{H}, \mathrm{N}$, and $\mathrm{S}$ contents were determined using an Elementar Vario MICRO elemental analyzer. The ash content was measured by thermogravimetric analysis using a Perkin-Elmer Pyris Diamond TG/DTA thermal analyzer over a temperature range of 30 to $800^{\circ} \mathrm{C}$ at a heating rate of $10{ }^{\circ} \mathrm{C} \mathrm{min}-1$. The solid-state ${ }^{13} \mathrm{C}$ CPMAS NMR spectra were recorded on a Bruker AVANCE III $400 \mathrm{WB}$ spectrometer equipped with a $4 \mathrm{~mm}$ standard bore CPMAS probehead whose $\mathrm{X}$ channel was tuned to $100.62 \mathrm{MHz}$ for ${ }^{13} \mathrm{C}$, and the other channel was tuned to $400.18 \mathrm{MHz}$ for broadband SPINAL64 ${ }^{1 \mathrm{H}}$ decoupling, using a magnetic field of $9.39 \mathrm{~T}$ at $298 \mathrm{~K}$. The dried and finely powdered samples (100-150 mg) were packed into $4 \mathrm{~mm}$ cylindrical $\mathrm{ZrO}_{2}$ rotors closed with Kel-F caps that were spun at $12 \mathrm{kHz}$ during acquisition. A total of 5000 or 10000 scans with 2048 data points were collected over a spectral width of $50 \mathrm{kHz}$, an acquisition time of $20 \mathrm{~ms}$, a recycle delay time of $3 \mathrm{~s}$, and a contact time of $2 \mathrm{~ms}$ for each sample. The Bruker TopSpin 3.2 software was used to collect and process the spectra. All the free induction decays (FIDs) were zero filled to 8,192 points and multiplied with a decaying exponential function equivalent to a line broadening of $100 \mathrm{~Hz}$ prior to Fourier transformation. The spectra were automatically phased and baseline corrected. All ${ }^{13} \mathrm{C}$ chemical shifts were referenced externally to the methylene resonance of adamantane $\left(\mathrm{C}_{10} \mathrm{H}_{16}\right)$ standard at $38.4 \mathrm{ppm}$. The spectra were divided into the following four integrating regions: alkyl C (0-50 ppm), O-alkyl C (50-110 ppm), aromatic C (110-160 ppm), and carbonyl C (160-210 ppm). The areas of the respective spectral regions were measured through the integration routine of the spectrometer and expressed as percentages of the sum of all spectral areas (i.e., relative intensity) (Pane et al., 2013). The natural valleys between signals are used as integration cut-off points (Rasyid et al., 1992). The spinning side band (SSB) was corrected by subtracting the area of the side band from that of the aromatic carbon region (Conte et al., 1997).

Table 1. Selected chemical and physical properties of the soils used in the study

\begin{tabular}{lcccccc}
\hline Soil & $\mathbf{p H}\left(\mathbf{H}_{\mathbf{2}} \mathbf{O}\right)$ & Organic carbon & Total nitrogen & Sand & Silt & Clay \\
\hline & & & & $\mathrm{g} \mathrm{kg}-1$ & & \\
Luvic Phaeozem & 6.50 & 11.2 & 1.08 & 472 & 256 & 272 \\
Hapic Chernozem & 7.92 & 13.7 & 1.21 & 505 & 320 & 175 \\
\hline
\end{tabular}




\section{RESULTS AND DISCUSSION}

The extraction yields, organic C recovery rates, ash contents, and elemental composition of bulk humin and its corresponding AS-humin and AIS-humin are shown in table 2. The organic C recovery rates of bulk humin after the $\mathrm{HF}-\mathrm{HCl}$ treatment were $73.3 \%$ for Luvic Phaeozem and $66.4 \%$ for Hapic Chernozem, respectively, indicating that most of the organic $\mathrm{C}$ was retained in the final samples (Zhou et al., 2014). The ash contents of bulk humin (36.8 and $39.6 \%$, respectively) were still high although the $\mathrm{HF}-\mathrm{HCl}$ treatment was repeated. Zhang et al. (2009) found that the ash contents of the humin from black soil were from 34.9 to $46.6 \%$ after treatment with different concentrations of the $\mathrm{HF}-\mathrm{HCl}$ solution. As expected, AS-humin had the lowest ash content (6.62 and $6.70 \%$ respectively) among the three humic components. After the organic matter-enriched AS-humin was isolated, the ash contents of AIS-humin (59.2 and $60.6 \%$ respectively) increased in a relative manner. In general, the $\mathrm{C}$ content followed the order AS-humin $>$ AIS-humin $>$ bulk humin, and for $\mathrm{H}$ and $\mathrm{N}$, the order was bulk humin $>$ AIS-humin $>$ AS-humin. This led to the $\mathrm{H} / \mathrm{C}$ ratio decreasing in the order bulk humin $>$ AIS-humin $>$ AS-humin, whereas the reverse was observed for the $\mathrm{C} / \mathrm{N}$ ratio. Higher $\mathrm{H} / \mathrm{C}$ and lower $\mathrm{C} / \mathrm{N}$ ratios imply a higher aliphaticity and maturity of humic substances, respectively (Nierop et al., 1999; Tan, 2003). Therefore, our results suggest that bulk humin was the most aliphatic and mature, followed by AIS-humin and AS-humin, which is in agreement with the result of the ${ }^{13} \mathrm{C}$ CPMAS NMR spectra (Table 3 ). In addition, the low $\mathrm{C} / \mathrm{N}$ ratio for the insoluble fraction of bulk humin suggests that it could be dominated by microbial residues (Lu et al., 2000).

Table 2. Extraction yields, organic carbon (OC) recovery rates, ash contents, and elemental composition of bulk humin and its corresponding alkaline-soluble humin (AS-humin) and alkaline-insoluble humin (AIS-humin) from Luvic Phaeozem and Hapic Chernozem

\begin{tabular}{|c|c|c|c|c|c|c|c|c|c|}
\hline Sample & Yield(1) & OC R(2) & Ash & $\mathbf{C}(3)$ & $\mathbf{H}^{(3)}$ & $\mathbf{N}(3)$ & $\mathbf{S}(3)$ & $\mathrm{H} / \mathrm{C}(4)$ & $\mathrm{C} / \mathrm{N}(4)$ \\
\hline \multicolumn{10}{|c|}{$\%$} \\
\hline \multicolumn{10}{|c|}{ Luvic Phaeozem } \\
\hline Bulk humin & 1.10 & 73.3 & 39.6 & 52.1 & 5.54 & 2.77 & 0.35 & 1.277 & 22.0 \\
\hline AS-humin & 0.11 & - & 6.70 & 65.8 & 4.04 & 1.74 & 0.64 & 0.736 & 44.1 \\
\hline AIS-humin & 0.62 & - & 59.2 & 59.0 & 4.78 & 2.55 & 1.63 & 0.972 & 27.0 \\
\hline \multicolumn{10}{|c|}{ Hapic Chernozem } \\
\hline Bulk humin & 0.99 & 66.4 & 36.8 & 50.4 & 5.87 & 4.90 & 0.34 & 1.398 & 12.0 \\
\hline AS-humin & 0.07 & - & 6.62 & 53.3 & 5.52 & 4.15 & 0.28 & 1.243 & 15.0 \\
\hline AIS-humin & 0.45 & - & 60.6 & 50.7 & 5.66 & 4.53 & 1.80 & 1.339 & 13.1 \\
\hline
\end{tabular}

(1) By mass; (2) OC recovery rate $=[($ extraction yield $\times$ OC of bulk humin after HF-HCl treatment)/OC of bulk humin before $\mathrm{HF}-\mathrm{HCl}$ treatment] $\times 100$; (3) On an ash-free basis; (4) Atomic ratio.

Table 3. Relative intensities of different carbon functional groups in solid-state 13C CPMAS NMR spectra of bulk humin and its corresponding alkaline-soluble humin (AS-humin) and alkaline-insoluble humin (AIS-humin) from Luvic Phaeozem and Hapic Chernozem

\begin{tabular}{|c|c|c|c|c|c|c|c|}
\hline \multirow[t]{2}{*}{ Sample } & Alkyl C & O-alkyl C & Aromatic C & Carbonyl C & \multirow[t]{2}{*}{$\mathrm{A} / \mathrm{O}-\mathrm{A}(1)$} & \multirow[t]{2}{*}{ Ali/Aro(2) } & \multirow[t]{2}{*}{ HB/HI(3) } \\
\hline & $0-50 \mathrm{ppm}$ & $50-110 \mathrm{ppm}$ & $110-160 \mathrm{ppm}$ & $160-210 \mathrm{ppm}$ & & & \\
\hline & \multicolumn{7}{|c|}{$\%$} \\
\hline & \multicolumn{7}{|c|}{ Luvic Phaeozem } \\
\hline Bulk humin & 28.8 & 30.0 & 31.2 & 9.98 & 0.959 & 1.887 & 1.499 \\
\hline AS-humin & 23.9 & 28.2 & 33.4 & 14.5 & 0.847 & 1.558 & 1.343 \\
\hline \multirow[t]{2}{*}{ AIS-humin } & 23.2 & 33.1 & 35.7 & 7.96 & 0.701 & 1.576 & 1.436 \\
\hline & \multicolumn{7}{|c|}{ Hapic Chernozem } \\
\hline Bulk humin & 35.4 & 31.3 & 17.6 & 15.6 & 1.132 & 3.781 & 1.131 \\
\hline AS-humin & 34.6 & 27.3 & 18.3 & 19.8 & 1.264 & 3.388 & 1.120 \\
\hline AIS-humin & 31.4 & 34.9 & 19.1 & 14.6 & 0.899 & 3.472 & 1.019 \\
\hline
\end{tabular}


Compared with the $\mathrm{H} / \mathrm{C}$ ratios of Luvic Phaeozem, the $\mathrm{H} / \mathrm{C}$ ratio of all the three humic components was higher whereas the $\mathrm{C} / \mathrm{N}$ ratio was lower in Hapic Chernozem. This indicated that the degree of aliphaticity and maturity of these humic components was higher in Hapic Chernozem than in Luvic Phaeozem, also in accordance with the result of the ${ }^{13} \mathrm{C}$ CPMAS NMR spectra (Table 3). Meanwhile, the lower $\mathrm{C} / \mathrm{N}$ ratio suggests that more microbiological reactions happen in Hapic Chernozem during the humification process (Lu et al., 2000). The differences between the two soils could be due to the different climates, soil textures, and land uses at the two sampling sites, as discussed below.

The solid-state ${ }^{13} \mathrm{C}$ CPMAS NMR spectra of bulk humin and its corresponding fractions are shown in figure 1 . These humic components had the features of the typical humin (Preston and Newman, 1995) and exhibited similar functional groups. The signals at around 22, 26, 31, 33, and $44 \mathrm{ppm}$ in the alkyl $\mathrm{C}$ region are ascribed to $-\mathrm{CH}_{3},-\mathrm{CH}_{2}-$, amorphous $-\left(\mathrm{CH}_{2}\right)_{\mathrm{n}}-$, crystalline $-\left(\mathrm{CH}_{2}\right)_{n}-$, and branched aliphatic $\mathrm{C}$, respectively. The peaks at around 56,62, 73, and $105 \mathrm{ppm}$ in the $\mathrm{O}$-alkyl $\mathrm{C}$ region are derived from methoxyl $\mathrm{C}$ in lignin, $-\mathrm{CH}_{2} \mathrm{OH}-,-\mathrm{CHOH}-$, and anomeric $\mathrm{C}$ in carbohydrate, respectively. The signals at around 127 and $152 \mathrm{ppm}$ in the aromatic $\mathrm{C}$ region are indicative of
$\mathrm{C}$ - and $\mathrm{H}$-substituted, and $\mathrm{O}$-substituted aromatic $\mathrm{C}$ from lignin, respectively. The signal at around $173 \mathrm{ppm}$ in the carbonyl $\mathrm{C}$ region represents carboxylic acid, amide, and ester. The signal at around $250 \mathrm{ppm}$ is assigned to side bands.

Although ${ }^{13} \mathrm{C}$ CPMAS NMR spectroscopy may underestimate nonprotonated aromatic $\mathrm{C}$ and carbonyl $\mathrm{C}$, it is still a suitable technique for semi-quantitative comparisons among different organic matter samples in soil (Zhang et al., 2011; Duarte et al., 2013; Zhou et al., 2014; Smernik and Kookana, 2015). The relative intensities of the $\mathrm{C}$ functional groups of bulk humin and its corresponding fractions differed, and the results are listed in table 3. Across all of the humic components of the two soils, the intensity of aliphatic $\mathrm{C}$ (the sum of alkyl $\mathrm{C}$ and O-alkyl C, 52.1 to $66.7 \%$ ) was greater than that of aromatic C (17.6 to $35.7 \%)$ and carbonyl C (7.96 to $19.8 \%)$. This result indicates that bulk humin and its corresponding fractions were more aliphatic in nature, which is consistent with previous results (Rice, 2001; Song et al., 2005; Spaccini et al., 2006; Zhang et al., 2013).

Irrespective of soil types, the intensities of alkyl C followed the order bulk humin $>$ AS-humin $>$ AIS-humin; for O-alkyl C, the order was AIS-humin $>$ bulk humin > AS-humin; for aromatic C, it was AIS-

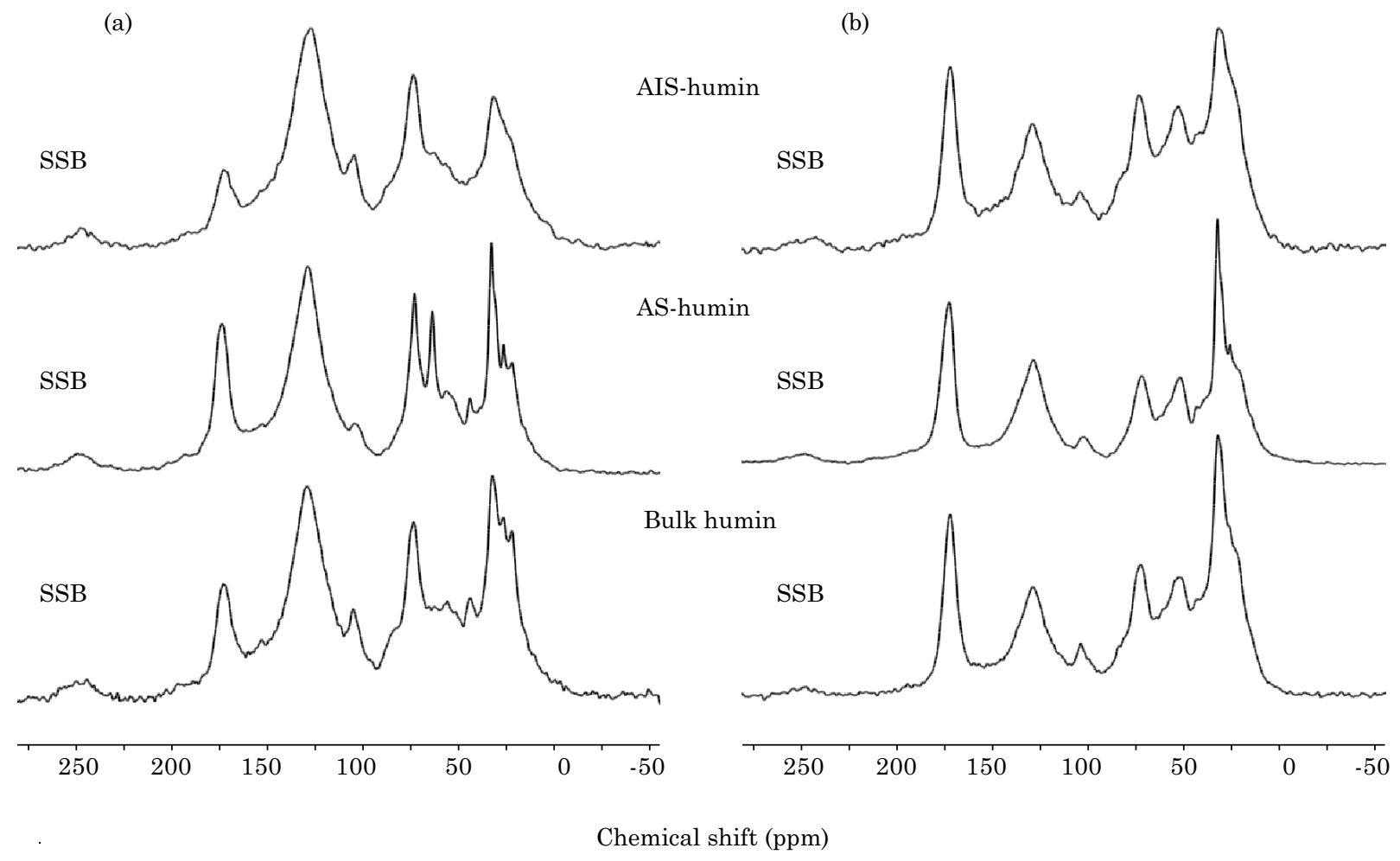

Figure 1. Solid-state ${ }^{13}$ C CPMAS NMR spectra of bulk humin and its corresponding alkaline-soluble humin (AS-humin) and alkaline-insoluble humin (AIS-humin) from Luvic Phaeozem (a) and Hapic Chernozem (b) (SSB = spinning side band). 
humin > AS-humin > bulk humin; and for carbonyl C, it was AS-humin > bulk humin > AIS-humin. These changes in the relative intensity of the different $\mathrm{C}$ functional groups resulted in the ratio of aliphatic $\mathrm{C}$ to aromatic $\mathrm{C}$ decreasing in the order bulk humin > AIShumin $>$ AS-humin. The ratios of alkyl $\mathrm{C}$ to O-alkyl C (alkyl C/O-alkyl C) and hydrophobic $\mathrm{C}$ to hydrophilic $\mathrm{C}$ (hydrophobic $\mathrm{C} /$ hydrophilic $\mathrm{C}$ ) decreased in the order bulk humin $>$ AS-humin $>$ AIS-humin, and bulk humin > AIS-humin > AS-humin in Luvic Phaeozem; and AS-humin $>$ bulk humin $>$ AIS-humin, and bulk humin > AS-humin > AIS-humin in Hapic Chernozem, respectively. The aliphatic C/aromatic C, alkyl C/O-alkyl C, and hydrophobic C/hydrophilic C ratios have been used as important indicators of the degrees of aliphaticity, alkylation, and hydrophobicity of humic substances, respectively. According to the literature (Zhang et al., 2009), higher values of aliphatic C/aromatic C, alkyl C/O-alkyl C, and hydrophobic $\mathrm{C} /$ hydrophilic $\mathrm{C}$ ratios indicate that humic substances are more aliphatic, alkylated, and hydrophobic. Therefore, our results suggest that bulk humin was the most aliphatic and most hydrophobic, AS-humin was the least aliphatic, and AIS-humin was the least alkylated among the humic components. In addition, the alkyl $\mathrm{C} / \mathrm{O}$-alkyl $\mathrm{C}$ ratio has also been proposed as an index to assess the degree of decomposition of humic substances, with a higher value indicating a higher degree of decomposition (Preston and Newman, 1995). In our study, the alkyl $\mathrm{C} / \mathrm{O}$-alkyl $\mathrm{C}$ ratio indicated that the soluble fraction in bulk humin was more easily decomposed as compared to the insoluble fraction of bulk humin. The differences in the intensities of the $\mathrm{C}$ functional groups of bulk humin and its fractions imply their different functions in soil. Zhang et al. (2013) showed that humin has an important function for the adsorption and desorption behavior of $\mathrm{Cu}$ (II) in soil. The carboxyl group in soil humin was responsible for this environmental process. Considering that the AS-humin had the higher intensity of the carbonyl group, we can thus infer from the present results that AS-humin rather than AIS-humin is the vital fraction for controlling the fate of metal ions in soil.

Compared with Luvic Phaeozem, the intensities of alkyl $\mathrm{C}$ and carbonyl $\mathrm{C}$, as well as the ratios of alkyl $\mathrm{C} / \mathrm{O}$-alkyl $\mathrm{C}$ and aliphatic C/aromatic $\mathrm{C}$ of all of the three humic components in Hapic Chernozem were higher, whereas the reverse was observed for the aromatic $\mathrm{C}$ content and the ratio of hydrophobic C/hydrophilic C. The results indicate that these humic components from Hapic Chernozem had higher degrees of alkylation and aliphaticity and a lower degree of hydrophobicity than those from Luvic Phaeozem. The above differences in the intensities of the $\mathrm{C}$ functional groups from the three humic components between the two soils can be explained by the different precipitations at the two sites. In accordance with the present results, previous studies showed that the aromaticity of soil humic substances declined with decreasing precipitations along temperate grassland climosequences in China (XI, 1998) and in Argentina (Martin-Neto et al., 1998). Low precipitation could delay organic matter turnover (Salamanca et al., 2003), which may restrict the formation of aromatic structures in soil humic substances.

These differences between soils can also be attributed to differences in soil texture and land use. According to Traversa et al. (2014), the organic matter from the cultivated soil with fine texture contained more aromatic $\mathrm{C}$ and less aliphatic compounds compared with that from undisturbed soil with coarse texture. The lower degree of decomposition of humin in Luvic Phaeozem than in Hapic Chernozem, as revealed by the alkyl C/O-alkyl $\mathrm{C}$ ratio, can be ascribed to the higher clay content in the former soil than in the latter soil. It is well known that clay protects organic matter against biological attack (Baldock and Skjemstad, 2000).

\section{CONCLUSIONS}

Bulk humin and its corresponding AS-humin and AIS-humin from Luvic Phaeozem and Hapic Chernozem had the features of typical humin and exhibited similar functional groups, including aliphatic hydrocarbon, carbohydrates, aromatics, carbonyl compounds, and others.

Regardless of soil types, bulk humin was the most aliphatic and most hydrophobic, AS-humin was the least aliphatic, and AIS-humin was the least alkylated among the three humic components.

The humic components from Hapic Chernozem had higher degrees of alkylation and aliphaticity and a lower degree of hydrophobicity than those from Luvic Phaeozem.

\section{ACKNOWLEDGMENTS}

This work was supported by the National Natural Science Foundation of China (41471196; 31470506), the National Key Technology R\&D Program (2013BAD07B02; 2013BAC09B01), and the Postdoctoral Project of Jilin Province (01912). We wish to thank Dr. Zijiang Jiang for his technical support in solid-state $13 \mathrm{C}$ NMR spectroscopy.

\section{REFERENCES}

Baldock JA, Skjemstad JO. Role of the soil matrix and minerals in protecting natural organic materials against biological attack. Org Geochem. 2000;31:697-710. 
Calace N, Petronio BM, Persia S, Pietroletti M, Pacioni D. A new analytical approach for humin determination in sediments and soils. Talanta. 2007;71:1444-8.

Cloos P, Badot C, Herbillon A. Interlayer formation of humin in smectites. Nature. 1981;289:391-3.

Conte P, Piccolo A, Van Lagen B, Buurman P, De Jager PA. Quantitative differences in evaluating soil humic substances by liquid- and solid-state ${ }^{13} \mathrm{C}-\mathrm{NMR}$ spectroscopy. Geoderma. 1997; 80:339-52.

Duarte RMBO, Fernández-Getino AP, Duarte AC. Humic acids as proxies for assessing different Mediterranean forest soils signatures using solid-state CPMAS ${ }^{13} \mathrm{C}$ NMR spectroscopy. Chemosphere. 2013;91:1556-65.

Food and Agriculture Organization of the United Nations/ International Soil References and Information Centre/ International Soil Science Society - FAO/ISRIC/ISSS. World reference base for soil resources. Rome: Food and Agriculture Organization of the United Nations, 1998.

Grinhut T, Hertkorn N, Schmitt-Kopplin P, Hadar Y, Chen Y. Mechanisms of humic acids degradation by white rot fungi explored using ${ }^{1} \mathrm{H}$ NMR spectroscopy and FTICR mass spectrometry. Environ Sci Technol. 2011;45:2748-54.

Kögel-Knabner I. ${ }^{13} \mathrm{C}$ and ${ }^{15} \mathrm{~N}$ NMR spectroscopy as a tool in soil organic matter studies. Geoderma. 1997;80:243-70.

Lao JC. Handbook of soil agro-chemistry analysis. Beijing: China Agriculture Press; 1988.

Lu XQ, Hanna JV, Johnson WD. Source indicators of humic substances: an elemental composition, solid state ${ }^{13} \mathrm{C}$ CP/MAS NMR and Py-GC/MS study. Appl Geochem. 2000;15:1019-33.

Martin-Neto L, Rosell R, Sposito G. Correlation of spectroscopic indicators of humification with mean annual rainfall along a temperate grassland climosequence. Geoderma. 1998;81:305-11.

Nierop KGJ, Buurman P, De Leeuw JW. Effect of vegetation on chemical composition of $\mathrm{H}$ horizons in incipient Podzols as characterized by ${ }^{13} \mathrm{C}$ NMR and pyrolysis-GC/MS. Geoderma. 1999;90:111-29.

Pallo FJP. Evolution of soil organic matter in some soils under shifting cultivation practices in Burkina Faso. In: Mulongoy $\mathrm{K}$, Merckx R, editors. Soil organic matter dynamics and sustainability of tropical agriculture. New York: John Wiley and Sons; 1993.

Pane C, Piccolo A, Spaccini R, Celano G, Villecco D, Zaccardelli M. Agricultural waste-based composts exhibiting suppressivity to diseases caused by the phytopathogenic soil-borne fungi Rhizoctonia solani and Sclerotinia minor. Appl Soil Ecol. 2013;65:43-51.

Preston CM, Newman RH. A long-term effect of N fertilization on the ${ }^{13} \mathrm{C}$ CPMAS NMR of de-ashed soil humin in a secondgrowth Douglas-fir stand of coastal British Columbia. Geoderma. 1995;68:229-41.

Rasyid U, Johnson WD, Wilson MA, Hann J. Changes in organic structural group composition of humic and fulvic acids with depth in sediments from similar geographical but different depositional environments. Org Geochem. 1992;18:521-29.

Rice JA. Humin. Soil Sci. 2001;166:848-57.

Salamanca EF, Kaneko N, Katagiri S. Rainfall manipulation effects on litter decomposition and the microbial biomass of the forest floor. Appl Soil Ecol. 2003;22:271-81.

Schmidt MWI, Knicker H, Hatcher PG, Kögel-Knabner, I. Improvement of ${ }^{13} \mathrm{C}$ and ${ }^{15} \mathrm{~N}$ CPMAS NMR spectra of bulk soils, particle size fractions and organic material by treatment with 10 \% hydrofluoric acid. Eur J Soi1 Sci. 1997;48:319-28.

Senesi N. Humic substances as natural nanoparticles ubiquitous in the environment. In: Xu J, Huang P, editors. Molecular environmental soil science at the interfaces in the earth's critical zone. Berlin: Springer-Verlag; 2010. p.249-250.

Smernik RJ, Kookana RS. The effects of organic matter-mineral interactions and organic matter chemistry on diuron sorption across a diverse range of soils. Chemosphere. 2015;119:99-104.

Song G, Hayes MHB, Novotny EH, Simpson AJ. Isolation and fractionation of soil humin using alkaline urea and dimethylsulphoxide plus sulphuric acid. Naturwissenschaften. 2011;98:7-13.

Song J, Peng P, Huang W. Characterization of humic acid-like material isolated from the humin fraction of a topsoil. Soil Sci. 2005;170:599-611.

Spaccini R, Mbagwu JSC, Conte P, Piccolo A. Changes of humic substances characteristics from forested to cultivated soils in Ethiopia. Geoderma. 2006;132:9-19.

Stevenson FJ. Humus chemistry: Genesis, composition, and reactions. New York: John Wiley and Sons; 1994.

Tan KM. Humic matter in soil and the environment: Principles and controversies. New York: Marcel Dekker; 2003.

Traversa A, D’orazio V, Mezzapesa GN, Bonifacio E, Farrag K, Senesi N, Brunetti G. Chemical and spectroscopic characteristics of humic acids and dissolved organic matter along two Alfisol profiles. Chemosphere. 2014;111:184-94.

Xi C. Soils of China. Beijing: Chinese Agriculture Press; 1998.

Zhang J, Dou S, Song X. Effect of long-term combined nitrogen and phosphorus fertilizer application on ${ }^{13} \mathrm{C}$ CPMAS NMR spectra of humin in a Typic Hapludoll of Northeast China. Eur J Soil Sci. 2009;60:966-73.

Zhang J, Hu F, Li H, Gao Q, Song X, Ke X, Wang L. Effects of earthworm activity on humus composition and humic acid characteristics of soil in a maize residue amended rice-wheat rotation agroecosystem. Appl Soil Ecol. 2011;51:1-8.

Zhang J, Wang S, Wang Q, Wang N, Li C, Wang L. First determination of $\mathrm{Cu}$ adsorption on soil humin. Environ Chem Lett. 2013;11:41-6.

Zhou Z, Chen N, Cao X, Chua T, Mao J, Mandel RD, et al. Composition of clay-fraction organic matter in Holocene Paleosols revealed by advanced solid-state NMR spectroscopy. Geoderma. 2014;223/225:54-61. 